\title{
Strategy of Organization and Safety of Road Traffic in the Russian Federation in the Conditions of Modern Urbanization
}

\author{
Igor Pugachev ${ }^{1}{ }^{*}$, Jrii Kulikov ${ }^{1}$, and Gennadii Markelov ${ }^{1}$ \\ ${ }^{1}$ Pacific National University,136 Tihookeanskaya str., Khabarovsk, 680035, Russia
}

\begin{abstract}
Abstract Directions of the modern approach to the organization and safety of traffic in the conditions of the emerging tendency to creation of agglomerations in the Russian Federation are defined. The complex of innovative concepts in the country related to the effective development of these agglomerations is considered. The functions of the Center providing the unifying beginning of the concepts under consideration are defined.
\end{abstract}

\section{Introduction}

The process of modern urbanization in our country is characterized by the prevalence of the urban population and the intensive growth of automobilization. The share of the urban population steadily makes up $74 \%$ of the total population of the Russian Federation (143 666.9 thousand people as of 01.01.2014). The average level of automobilization according to the Federal State Statistics Service as of January 1, 2016 amounted to 300 own cars for 1000 people of population and exceeded by 2.3 times the level of 2000 . The uncontrolled growth of urban motorization has created a crisis state of service of the population by all kinds of urban street transport, especially during peak hours: the formation of traffic congestion much reduces the speed of passenger communication and the speed of rapid delivery of goods by street transport; urban atmosphere is polluted with exhausted car gases; is increased traffic noise; is increased accidents on the roads; is blocked traffic of special transport of emergency services of the city; is complicated the urban construction problems related to the reconstruction of the street and road network, parking and storage of cars and other problems.

\section{Material and methods}

At the same time appeared a tendency to create agglomerations. Were developed a programs for the integrated development of transport infrastructure (SCRTI) for settlements, urban districts and agglomerations within the framework of the priority direction of Russia's strategic development "Safe and Qualitative Roads" (BKD), proposed by the President of the Russian Federation, which was launched in 2017. The main

*Corresponding author: ipugachev@mail.khstu.ru 
objectives of this global project are to bring the road network to the normative transport and operational status and to ensure the necessary level of traffic safety on the road network through the main targets - reduction sources of accidents and increase the proportion of roads in the regulatory state in the target values: by 2018 - not less than $50 \%$, by 2025 - not less than $85 \%$. Total in the BKD project participate 37 agglomerations with a population of more than 500 thousand people in 34 constituent entities of the Russian Federation. Particular importance have agglomerations in the regions of the Far East associated with the development of "Far Eastern hectares."

Problems of the development of the infrastructure of large cities were considered by a large number of domestic and foreign scientists. So efficiency within municipal transportation is considered in [1]; problems of designing transport networks of large cities are disclosed in [2]; the development of the city's transport infrastructure in the context of the explosive growth of automobilization has been reviewed [3]; the use of underground city space for transport infrastructure is reviewed in detail [4]; financial support for the construction of transport infrastructures is devoted to research [5]; Attention has been given to public transport information [6]; Equilibrium demand models between transportation demand and infrastructure capabilities are addressed in [7]; The introduction of unmanned electric vehicles on UDS of large cities is described in $[8,10]$; Modeling public transport networks is the subject of [9].

Due to the high level of traffic accidents in the Russian Federation, especially in the cities and agglomerations, which account for up to $70 \%$ of road accidents (RTA) in Russia, more than $40 \%$ of them die and injured more than $65 \%$ of the total number of injured $[11,12]$, the development of the project of Strategy for the organization and safety of road traffic in the Russian Federation for the medium term, in our opinion, requires an orientation to innovative concepts, to which primarily include the "Safe City" and "Intellectual City", which are based on hardware and software complexes, providing gathering of information, automated control of urban transport systems, satellite monitoring of transport with the subsequent transition to the creation of ground unmanned vehicles and the use of unmanned vehicles in transport within the framework of the Strategy for Scientific and Technological Development of the Russian Federation, approved by Presidential Decree No. 642 of December 1, 2016 [13,14,15,16,17]. The integrated concept of urbanization is the "Comfortable City" within the framework of the implementation of the priority federal project "Building a Comfortful Urban Environment" in accordance with the Rules for Co-financing of Subjects of the Russian Federation, approved by Resolution of the Government of the Russian Federation of February 10, 2017 No. 169. At the same time, indicators of the quality of transport services of the population and their normative values are given in the social standard approved by the decree of the Ministry of Transport of Russia on January 31, 2017 No. NA-19-r. [18]

\section{Theory}

Road traffic in cities is a complicated dynamic system, the main indicators of its effectiveness are speed and road safety. From the position of the system approach, the problems of organization and safety of the urban movement require solutions to not only technical and transport town planning tasks, but also joint activities of transport and road enterprises, traffic police (STSI), public, scientific, educational and other organizations related to the road safety system (BDD), as well as authorities different levels. At the same time, critical factors can come from any decision, which requires expert evaluation $[19,20]$.

The unprecedented development of information, intellectual transport and telecommunication systems and technologies has opened new opportunities for solving complex transport problems that the modern world faces [21]. 
An example of such opportunities is the creation in the Khabarovsk Territory, in the concept with the hardware and software complex "Safe City", of a single Center for Road Safety, which provides the following functions:

- daily information gathering about the current transport-operational condition of highways, emergency situations on highways of regional and inter-municipal importance;

- the organization of work of the dispatching service for control of the current state of highways and fast reaction to the elimination of problems identified by the dispatching service;

- the gathering, generalization and processing of operational information about the parameters of traffic flows, weight parameters of vehicles, meteorological conditions, traffic conditions, the state of the road and artificial structures on it, the performance of road works, the level of maintenance and transport and operational status, violations of the Road Traffic Rules on the highways of the regional or intermunicipal significance of the Khabarovsk Territory;

- bringing to the participants of BDD information on problem issues arising on the roads of the region;

- analysis of information received on the state of movement of vehicles on regional or inter-municipal highways and preparation of operational reports;

- analysis and forecast of changes in the parameters of the traffic flow taking into account the road traffic situation and road conditions;

- declaration of the place of concentration of road accidents (RTA) on regional roads and violations of the Road Traffic Rules; the results of the analysis in the form of operational reports are sent to the participants of the road safety system (BDD); procedure, form, frequency, recommendations and system for monitoring the implementation of recommendations of operational reports for the participants of the road safety system (BDD) is determined by the Governor's order;

- drawing up maps of places of concentration of road accidents (RTA) and dangerous areas on regional and municipal roads;

- identification of violations of the Rules of the road in terms of exceeding the established speed limits and weight restrictions;

- creation of electronic library for the participants of the road safety system (BDD);

- installation, maintenance and exploitation of video fixing systems for identify violations of the Road Traffic Regulations;

- registration, systematization and archiving of incoming materials on the transportoperational condition of highways of regional or inter-municipal significance of the Khabarovsk Territory;

- provision to officials of road organizations the necessary information on concerning road traffic and transport-operational condition of highways;

- receiving information from Roshydromet about extreme hydrometeorological conditions and timely bringing it to the road management authorities;

- implementation of interactions in the field of improving the level of road safety and organization of traffic on the regional or inter-municipal highways of the Khabarovsk Territory with the administration of the traffic police (STSI) of the Ministry of Internal Affairs for the Khabarovsk Territory, the FKU "Dalupravtodor", the Ministry of Emergency Situations for the Khabarovsk Territory, the Federal State Institution "Khabarovsk CGMSRSMC" municipalities, the Far Eastern Interregional Directorate of State Road Supervision and other organizations of the Khabarovsk Territory;

- creation and maintenance of a contact line for gathering information on problematic issues of road safety (BDD) from the participants of the road safety system (BDD), organizations and citizens. 


\section{Results}

Thus, the availability of operational information and real-time contact information allows for coordination and interaction of the various interdepartmental services providing the organization and road safety (BDD), and also to identify cause-effect relationships that contribute to the occurrence of accidents (RTA) and injuries.

\section{Discussion}

Implementation of concept the "Safe City" requires the use not only of technical capabilities for monitoring the condition of transport infrastructure, environment, organization and road safety system (BDD), but also the creation of an integrated scheme for interaction and coordination of services in the organization and road safety (BDD) in three aspects: management, regulatory-legal and organizational-technical.

\section{Conclusions}

The regional road safety system (BDD) established in Khabarovsk, as mentioned above, functions on the basis of the regional road safety (BDD) center, the program material of its functioning is the regional strategiac document "The concept of road safety and the program of measures on the territory of the Khabarovsk Territory" developed by the Pacific National University (PNU) [22].

\section{References}

1. P. Zito, G. Salvo, Toward an urban transport sustainability index: An european comparison. European Transport Research Review, 3(4), pp.179-195. doi:10.1007/s12544-011-0059-0 (2011)

2. B. J. Vitins, K. W. Axhausen, Optimization of large transport networks using the ant colony heuristic. Computer-Aided Civil and Infrastructure Engineering, 24(1), pp. 114. doi:10.1111/j.1467-8667.2008.00569.x (2008)

3. R. Liu, C. Guan, Mode biases of urban transportation policies in china and their implications. Journal of Urban Planning and Development, 131(2), pp. 58-70. doi:10.1061/(ASCE)0733-9488(2005)131:2(58) (2005)

4. W. Broere, Urban underground space: Solving the problems of today's cities. Tunnelling and Underground Space Technology, 55, pp. 245-248. doi:10.1016/j.tust.2015.11.012 (2016)

5. T. R. Leinbach, Transport and third world development: Review, issues, and prescription. Transportation Research Part A, 29(5), pp. 337-344. doi:10.1016/09658564(94)00035-9 (1995)

6. A. Lima, R. Stanojevic, D. Papagiannaki, P. Rodriguez, M. C. González, Understanding individual routing behaviour. Journal of the Royal Society Interface, 13(116) doi:10.1098/rsif.2016.0021 (2016).

7. Y. Jin, M. Echenique, A. Hargreaves, A recursive spatial equilibrium model for planning large-scale urban change. Environment and Planning B: Planning and Design, 40(6), pp. 1027-1050. doi:10.1068/b39134 (2013).

8. T. T. Taefi, J. Kreutzfeldt, T. Held, A. Fink, Supporting the adoption of electric vehicles in urban road freight transport - A multi-criteria analysis of policy measures 
in germany. Transportation Research Part A: Policy and Practice, 91, pp. 61-79. doi:10.1016/j.tra.2016.06.003 (2016).

9. F. Meng, G. Liu, Z. Yang, M. Casazza, S. Cui, S. Ulgiati, Energy efficiency of urban transportation system in xiamen, china. an integrated approach. Applied Energy, 186, 234-248. doi:10.1016/j.apenergy.2016.02.055 (2017).

10. I.N. Pugachev, Yu. I. Kulikov, Accident in motor transport. Transport safety and technology, 1 (32), pp. 114-117 (2013)

11. I. Pugachev, Y. Kulikov, G. Markelov, N. Sheshera, Factor Analysis of Traffic Organization and Safety Systems. Transportation Research Procedures, 20, 12th International Conference "Organization and Traffic Safety Management in large cities", SPbOTSIC - 2016, 28-30 September 2016; Petersburg, Russia, pp. 529-535 (2017)

12. I.N. Pugachev, G. Ya. Markelov, Intellectual management of urban transport systems. Transport and service: a collection of scientific papers. Kaliningrad: Publishing House. I. Kant, 2: The functioning of sustainable urban transport systems, pp. 58-66 (2014)

13. I.N. Pugachev, Methodology for the development and implementation of the concept of road safety and program activities on the territory of the subject (the example of the Khabarovsk Territory). Khabarovsk: The Pacific Publishing House. state. Univ. (2016)

14. I. N. Pugachev, G. Ya. Markelov, E. D. Saltanova, Features of the implementation of satellite monitoring systems at enterprises. Information technologies and innovations in transport: materials of the international. scientific and practical conference, under the general editorship of A.N. Novikov. Eagle: Publishing House of the State University-UNPK, pp. 58-62 (2015)

15. I. N. Pugachev, Yu. I. Kulikov, Strategy of modernization and innovative development of transport infrastructures and technologies. Transport and service: a collection of scientific papers. Kaliningrad: Publishing house of BFU. I. Kant, 3: Development of the city's transport system. pp. 9-16 (2015)

16. I. Pugachev, A. Alarmolinskii, A. Vasilyev, Improving the criteria for determining the dates of repair of highways. Transportation Research Procedures, 27, 10th International Scientific Conference "Transbaltica 2017: Transportation Science and Technology" 28-30 February 2016; Khabarovsk, Russia, pp. 429-435 (2017)

17. I. Pugachev, A. Kamenchukov, Perspective methods of assessing the quality and safety of road traffic. International Scientific and Research Journal, 01 (55). Part 4.January. pp. $72-75$ (2017)

18. I. Pugachev, Yu. Kulikov, S.Waksman, Normative and legal support of transport functioning of cities. Socio-economic problems of development and functioning of city transport systems and zones of their influence: Volume I materials XXIIIMezhdunar. (twenty-sixth of Ekaterinburg) scientific-practical. Conf. (June 16-17, 2017) / scientific. Ed.: S.A. Waksman. - Ekaterinburg: Publishing house AMB, pp. 69-74 (2017)

19. I. Pugachev, G. Markelov, T. Kondratenko, Y. Kulikov, Strategy of transport systems development in Russian cities: monograph. Khabarovsk: Publishing house Pacific. state. University (2017)

20. I. Pugachev, G. Markelov, S. Plesovskikh, S. Burkov, Monitoring system based on satellite navigation (monograph). Khabarovsk: Publishing house Pacific. state. University (2015) 
21. I. Pugachev, S. Burkov, G. Markelov, A. Oleynik, Development strategy of the use of intelligent transport systems in urban traffic management. Khabarovsk: Publishing house Pacific. state. University (2013)

22. I. Pugachev, S. Burkov, G. Markelov, ITS formation. The technique of infrastructure research on the example of the city of Khabarovsk (monograph). Khabarovsk:

Publishing house Pacific. state. University (2013) 